\title{
取水堰の操作が河川の水面形と下流部の流況に及ぼす影響評価
}

\author{
阿南光政 ${ }^{1} ・$ 水落二郎 $^{1} ・$ 演田耕佑 ${ }^{2} ・$ 弓削こずえ ${ }^{3}$

\section{Evaluation of River Surface Water Profile and Effect on the Downstream Current under Diversion Weir Control}

\author{
Mitsumasa Anan ${ }^{1}$, Jiro Mizuochi ${ }^{1}$, Kosuke Hamada $^{2}$ and Kozue Yuge ${ }^{3}$
}

\begin{abstract}
Prompt gate control of diversion weirs is required to flow the excess water under the flood condition. It is also important for gate opening method of diversion weir to ensure safety and simplicity to prevent the water accidents and human errors. The aim of this study is to develop the optimal method of gate opening method of diversion weir under the flood condition. A simulation model describing one dimensional unsteady flow was introduced to evaluate the effect of the gate opening of multiple diversion weirs on the downstream current. Using this model, the surface water profile was estimated under the different patterns of gate opening procedure. The simulateds result indicated that the fluctuation of water level and extent of impact by gate opening varied with the speed of the gate opening. The appropriate speed of the gate opening was clarified to reduce the fluctuation of water level by gate opening under the flood condition. The method introduced in this study is effective to develop the optimal gate control method of the diversion weirs for not only prompt flood protection but also safety.
\end{abstract}

Keywords: Unsteady flow; Head works; Surface water track; Flood control; Gate opening; River administration

1 はじめに

農業用水の取水堰の設計においては, 受益地の灌泊に 必要な水位や水量を適切に確保できるよう計画するととも に, 洪水時の通水阻害や溢水の要因とならないよう治水 機能に留意することも重要である. 近年, 集中豪雨による 洪水が各地で頻発しており, 洪水を防止するためには速 やかに流下させるような堰ゲート操作が必要である. しかし， 昨今の農業従事者の高齢化や土地改良区の機能低下か ら, 取水施設の適正な維持管理が困難な状況となってい る(勝山ら, 2012). さらには, 管理作業中の水難事故やヒ ユーマンエラーも発生しており, 管理の安全性の向上およ び簡素化も求められている(中橋ら, 2006).このため, 洪 水時における堰の管理規程は, 迅速性および安全面の両 者を向上させるように合理的に定められることが，管理者 の安全および周辺地域の治水において極めて重要である. 取水堰の老朽化に伴う更新事業や, 治水機能向上のため に固定堰を可動堰へ改修する事業が全国各地で行われ ており,こうした合理的な運用マニュアルのニーズは今後 ますま寸高まるであろう.

河川で取水堰のゲートの操作を行うと水位の変動が生 じ,この影響は下流部に及ぶ. したがって, 取水堰の管理 規程を定める際には，下流部で著しい水位変動が生じな いよう配慮する必要がある.こうした下流への流況への影 響をなるべく抑制するように, 取水堰の水理構造に様々な

1 (株) 高崎総合コンサルタント, Takasaki Sogo Consultant, Co. Ltd., 3-7-5 Higashiaikawa, Kurume, 839-0809, Japan

2 九州大学大学院生物資源環境科学府, Graduate School of Bioresource and Bioenvironmental Sciences, Kyushu University, 6-10-1 Hakozaki Higashi-ku, Fukuoka 812-8581, Japan

3 佐賀大学農学部准教授, Associate Professor, Faculty of Agriculture, Saga University, 1 Honjo Saga, 840-8502, Japan (Corresponding Author) E-mail:yuge@cc.saga-u.ac.jp
工夫を加えるための研究が行われている(中ら, 2002).こ うしたハード面への工夫に加え, 洪水時には堰ゲートの倒 伏あるいは起立などの管理に伴う下流部への水位変動へ の影響も明らかにし，これを極力軽減するような管理規程 を定めることが必要である.

河川内の単体の取水堰のゲー卜操作に伴う下流の水位 変動は, 不等流解析によって評価することができる. しかし， 我が国の河川では, 短い河道区間内に複数の取水堰が 設置されているケースが多い. 個々の取水堰のゲート操作 によって河川の水位変動は非常に複雑で時間とともに変 化するため, こうしたケースで水面追跡を行う場合は不定 流解析が必要となる. 竹村ら (2010) は, 小規模な発電用 ダムが連続する河川におけるゲート操作が洪水流の伝播 と貯留に及ぼす影響を不定流解析によって評価している. 発電用ダムの放流操作によって, 下流部一の流況が影響 を受け, 精度よく流量を推定することが難しいことも指摘さ れている(鈴木ら, 2011)。一般に, 農業用水の取水堰は 発電用ダムに比べると規模は小さいが, 短い河道区間内 に密集しているケースが多い.さらには, わが国の河川は 比較的急峻であるため, 洪水時のゲート操作による下流 部への影響はより複雑になると考えられるが,こうした現象 を明らかにした例は見当たらない。

洪水時の堰ゲート操作に伴って堰下流の流況は急激に 変化する. こうした際の水面形を洪水時に実測によって明 らかにすることは危険性が極めて高く, 精度の良い測定結 果を得ることが難しい. そのため, 堰のゲート操作による影 響が下流部にどのように伝播するかを明らかにするには， 精度が高く, 信頼性の担保された水理モデルを用いること が適切であると考えられる。

本研究では, 複数の取水堰が存在している河川を対象 に, 洪水時の堰群のゲート倒伏に伴う水位変動を明らか 
にするための手法を構築し, 適切な堰兮一ト操作の管理 規程を具体的に提言することを目的とする. 対象河川とし て, 北部九州の遠賀川水系を選定し, 複数の取水堰が存 在する区間において, MIKE 11(DHI, 2009)を導入し, 堰 群のゲート操作を考慮した一次元不定流解析を行った。 MIKEは, 水理, 水文および水質をシミュレートするモデル であり，一次元場から三次元場における適用が可能である。 MIKEは複数のモジュールで構成されているが, 本研究で 導入したMIKE 11は一次元場を対象としており, 河川にお ける流出解析や水理解析に広く用いられている. こうした 水理・水文モデルは多数発表されているが, 国土交通省 では我が国の流出特性を考慮して, 十分な信頼性と精度 が既に確認されているInfoWorks CS，xpswmmおよび MIKEを用いて流出解析を行うことを推奨している.

MIKE 11では, 河川に存在する取水堰などの水利施設 を考慮した水理解析が可能である. 海外の河川において 水利施設を考慮した水面追跡や流出解析に用いられ, 極 めて精度が良く, 再現性が高いことが報告されている (Kamel, 2008; Timbadiya et al., 2014; Wijesekara et al., 2014). 本研究では, これらの既往の研究で十分な精度が 確認されている本モデルを援用して, 洪水時のゲート倒伏 を考慮した水面追跡を行い, 堰群のゲート操作が下流の 水位変動に及ぼす影響を解明した.さらに, 各取水堰の ゲー卜操作条件を様々に設定し, 洪水時における安全性 かつ迅速性の両者を担保するような最適な操作条件の探 索を試みた。

\section{2 対象河川の概要}

本研究では, 北部九州を流れる遠賀川の上流部を対象と した. 遠賀川は延長 $61 \mathrm{~km}$, 流域面積 $1026 \mathrm{~km}^{2}$ の一級河川 である. 対象区間は図 1 に示した通り, 水位・流量観測所 である大隈 $(45.2 \mathrm{k})$ から川島 $(30.5 \mathrm{k})$ の間の約 $15 \mathrm{~km}$ である. 対象区間の縦断図を図 2 に示す. 対象地区の高低差は

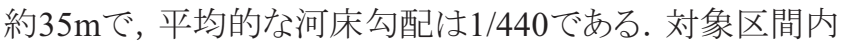
には既設の取水堰が8か所存在しており, 洗越堰は固定 堰で, その他は可動堰である.このうち, 戸倉堰および柳 原堰が2010年7月 13日〜14日に発生した日雨量224mmの 豪雨によって被災した。両取水堰は堤体本体が $2 / 3$ 以上流 出し, 残存部も堤体に亀裂が入ったり, 洗掘されるなどの
被害を受けた。このため, これらを統合した戸倉・柳原統 合堰 (以下, 統合堰)を設け, 受益地に灌湎用水を取水す るための事業が計画および実施された. 表 1 に統合堰の 改築後の諸元を示す. また, その他の可動堰の洪水時に おける管理規程を表 2に示している.この表に示した通り， 各堰には倒伏を開始する越流水深および倒伏を開始して 終了させるまでの時間が定められ，これを基準として洪水 時にゲート操作が行われる. 特に, 倒伏時間は洪水時の 堰ゲートの倒伏の際に下流に著しい水位変動が生じない ように定められている重要な項目である. 改修後の統合堰

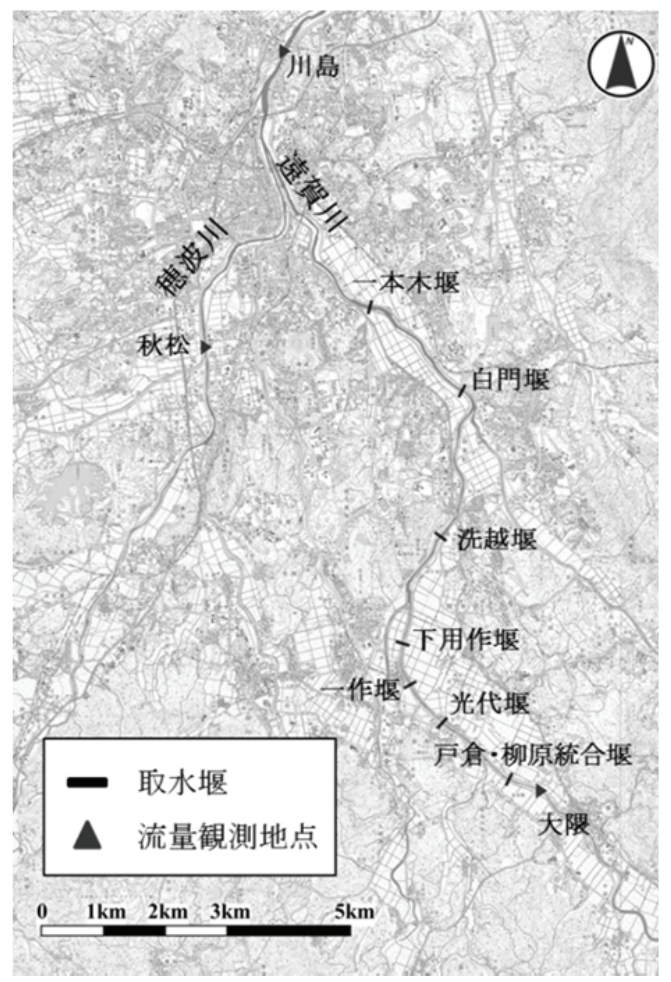

図 1: 対象河川における取水堰および水位・流量観測 所の位置

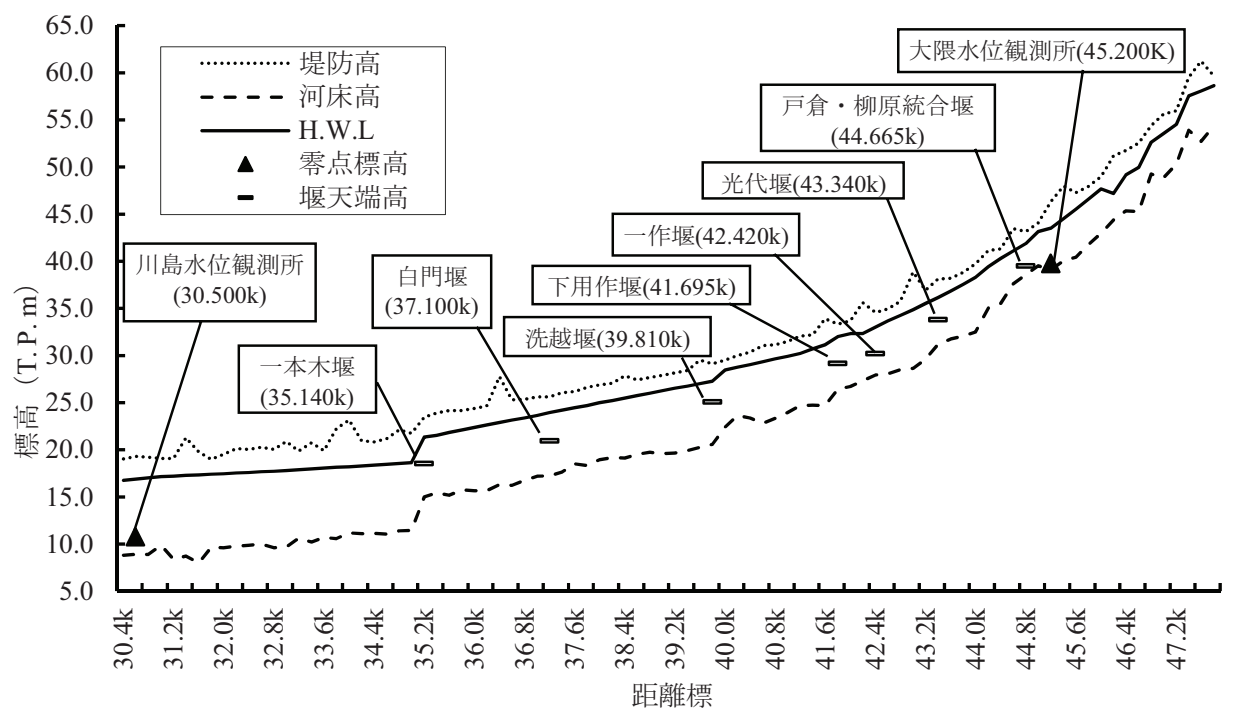

図 2 : 対象区間の河床標高, 河川堤防高および高水位（H. W. L） 
表 1: 戸倉・柳原統合堰における基礎諸元

\begin{tabular}{c|c}
\hline 項目 & 諸元 \\
\hline 位置 \\
目的 \\
形式 \\
遠賀川 $40.665 \mathrm{k}$ \\
農業用水 \\
エ゙ム引布製起伏堰 \\
$\begin{array}{c}\text { 倒伏条件 } \\
\text { (越流水深, m) } \\
\text { 堰高 }(\mathrm{m}) \\
\text { ゲート幅員 }(\mathrm{m})\end{array}$ \\
\hline
\end{tabular}

表 2: 既存可動堰の形状と倒伏条件

\begin{tabular}{|c|c|c|c|}
\hline \multirow[b]{2}{*}{ 堰名 } & \multirow[b]{2}{*}{ 堰の形式 } & \multicolumn{2}{|c|}{ 倒伏条件 } \\
\hline & & $\begin{array}{c}\text { 越流水深 } \\
(\mathrm{m})\end{array}$ & $\begin{array}{c}\text { 倒伏時間 } \\
\text { (分) }\end{array}$ \\
\hline 一本木 & $\begin{array}{c}\text { ゴム引布製 } \\
\text { 起伏堰 }\end{array}$ & 0.40 & 40 \\
\hline 白門 & $\begin{array}{c}\text { ゴム引布製 } \\
\text { 起伏堰 }\end{array}$ & 0.60 & 40 \\
\hline 下用作 & 鉄製転倒堰 & 0.25 & 15 \\
\hline 一作 & 鉄製転倒堰 & 0.30 & 15 \\
\hline 光代 & $\begin{array}{c}\text { ゴム引布製 } \\
\text { 起伏堰 }\end{array}$ & 0.40 & 30 \\
\hline
\end{tabular}

は対象区間の上流部に位置していることから, 特に下流へ の影響に留意して最適な倒伏時間を決定する必要がある. また, 表 2に示した倒伏時間は単独の堰の操作上の都合 や安全性によって規定されているものであり, 堰群が同時 に操作された時の水位変動は考慮されていない.これらの 堰は老朽化しているものも多く, 今後改修する必要が生じ ると考えられるが，その際には他の堰のゲート操作の影響 を考慮に入れて倒伏条件を再検討する必要がある.

\section{3 取水堰のゲート操作を考慮した河川水面追跡のモデ リング}

\section{1 基礎方程式}

単体の堰の倒伏や起立に伴う水位変動は, 不等流解析に よって求めることができる. 一方, 本研究の対象地区のよう に複数の堰が存在する場合は, 個々の堰の倒伏や起立 は相互の流況に影響を及ぼし, 水位は時間的および空間 的に変化する. そのため, こうしたケースにおける河川水 面の追跡を行う場合には不定流解析を行う必要がある. 本研究では, 可動堰の倒伏に伴う河川の水面を追跡する モデルとしてMIKE 11を導入し, 一次元不定流解析を行 った. 本モデルでは, 次式で表現される運動方程式およ び連続の式を用いて不定流解析を行うことができる.

$$
\begin{gathered}
\frac{1}{g}\left[\frac{\partial v}{\partial t}\right]+\frac{1}{g} \frac{\partial}{\partial x}\left[\frac{v^{2}}{2}\right]+S+\frac{\partial h}{\partial x}+\frac{n^{2}|v|}{R^{4 / 3}} v=0 \\
\frac{\partial A}{\partial t}+\frac{\partial Q}{\partial x}-q=0
\end{gathered}
$$

ここで, $g$ : 重力加速度 $\left(\mathrm{m} \mathrm{s}^{-2}\right), v$ : 流速 (上流へ向けて正, $\left.\mathrm{m} \mathrm{s}^{-1}\right), S$ : 河床勾配, $h$ : 水深 $(\mathrm{m}), n$ : 粗度係数, $x$ : 区間距 離 $(\mathrm{m}), t$ : 時間 $(\mathrm{s}), A$ : 通水断面積 $\left(\mathrm{m}^{2}\right), Q$ : 通過流量 $\left(\mathrm{m}^{3}\right.$ $\left.\mathrm{s}^{-1}\right), q$ : 横流入量 $\left(\mathrm{m}^{3} \mathrm{~s}^{-1} \mathrm{~m}^{-1}\right)$ である.

図 3は河道内における計算格子の模式図を示している. この図に示した通り, 流量(または流速)および水深の計算 格子を交互に設定し, 式(1)および(2)を解くことによって時 間ごとの流量および水深を求める. 本モデルにおいては, Abbott and Ionescu (1967)によって提案された有限差分 法によって式(1)および(2)を次式のとおり離散化し, 図 4 に示した中心格子位置の流量および水深を推定すること とした.

$$
\frac{1}{g}\left[\frac{v_{j}^{n+1}-v_{j}^{n}}{\Delta t}\right]+\frac{1}{g}\left[\frac{\left(v_{j+1}^{n+1 / 2}\right)^{2}-\left(v_{j-1}^{n+1 / 2}\right)^{2}}{2 \Delta x_{j}}\right]+S
$$

$$
+\frac{\frac{h_{j+1}^{n+1}+h_{j+1}^{n}}{2}-\frac{h_{j-1}^{n+1}+h_{j-1}^{n}}{2}}{2 \Delta x_{j}}
$$

$$
+\frac{1}{2}\left[\frac{n^{2}\left|v_{j+1}^{n+1}\right| v_{j+1}^{n}+n^{2}\left|v_{j-1}^{n+1}\right| v_{j-1}^{n}}{\left(\frac{R_{j+1}^{n}+R_{j-1}^{n}}{2}\right)^{4 / 3}}\right]=0
$$

$$
\begin{aligned}
& \frac{A_{j}+A_{j+1}}{2 \Delta x} \cdot \frac{h_{j}^{n+1}-h_{j}^{n}}{\Delta t} \\
& +\frac{\frac{Q_{j+1}^{n+1}+Q_{j+1}^{n}}{2}-\frac{Q_{j-1}^{n+1}+Q_{j-1}^{n}}{2}}{2 \Delta x_{j}}-q_{j}=0
\end{aligned}
$$

取水堰地点の流量は, 次式で示されるVillemonte (1947) の式を適用して計算した(図 5).

$$
\begin{gathered}
Q=Q c\left\{1-\left(\frac{h_{2}}{h_{1}}\right)^{1.5}\right\}^{0.385} \\
Q c=1.8 \times B \times h_{1}^{1.5}
\end{gathered}
$$

計算区間内において, 堰が図 3 に示した流量の計算格 子に位置するように設定し, その前後の水位や流量の時 間変化を解析することとした。

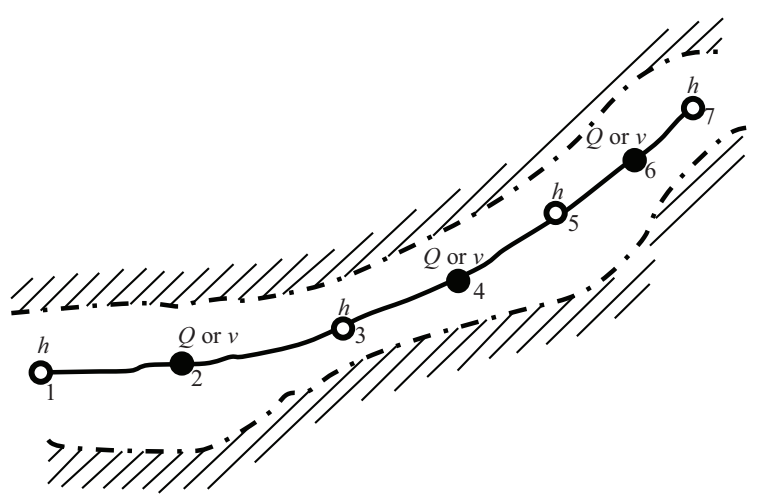

図 $3:$ 計算格子の概念困 


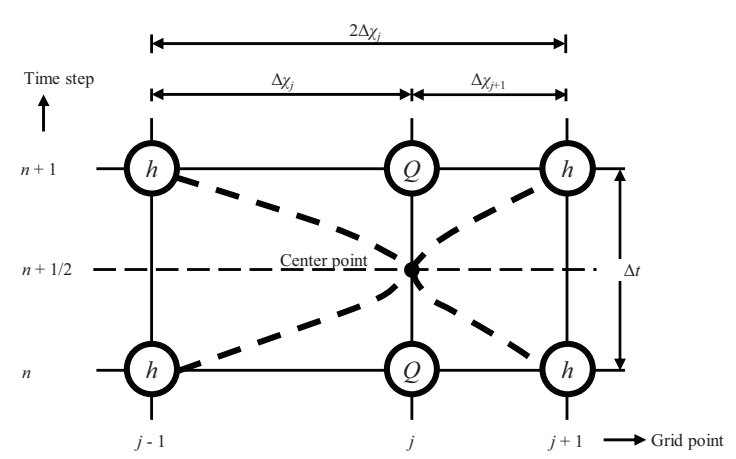

(a) 運動方程式

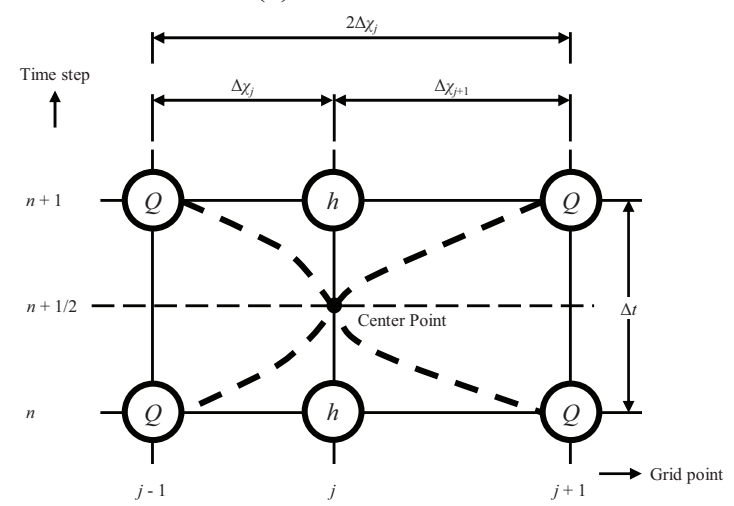

(b) 連続の式

図 4:基礎方程式の離散化および計算方法の概要

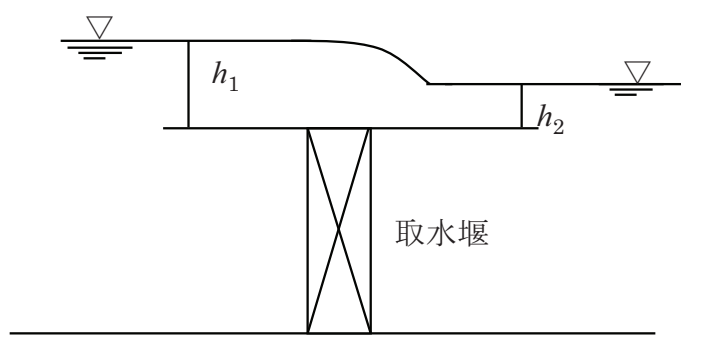

図 5 : 堰位置の上下流の水位を用いた越流量の計算

\section{2 堰の倒伏動作の設定}

図 5に示した通り, 堰位置では堰前後の水位を用いて流 量を求め, 河道全体の不定流解析に用いる. 洪水の際, 堰が転倒を始めると, 堰前後の水位は徐々に変化する. 図 6は堰ゲートの倒伏動作のモデル化の概要を示したも のである.この図に示した通り, 堰地点の計算水位が倒伏 開始水位に達した時点において, 倒伏動作を開始するよ う堰ごとに条件を与えた. 倒伏開始から完全倒伏に要する 時間を倒伏時間 $t_{w}(\mathrm{~s})$ とし, 堰高 $H_{w}(\mathrm{~m})$ を倒伏する速度 $v_{w}\left(\mathrm{~m} \mathrm{~s}^{-1}\right)$ を次式で与えた。

$$
v_{w}=\frac{H_{w}}{t_{w}}
$$

式(7)の $t_{w}$ を様々に設定することにより, 堰の倒伏速度を変 化させた。倒伏開始から完全倒伏に至るまでの堰高が 刻々と変化し，これに伴って図 5 に示した堰の上下流の 水位も変動するように設定した. 図 4に示した通り, これら を用いることによって堰の下流部の水面を追跡した。
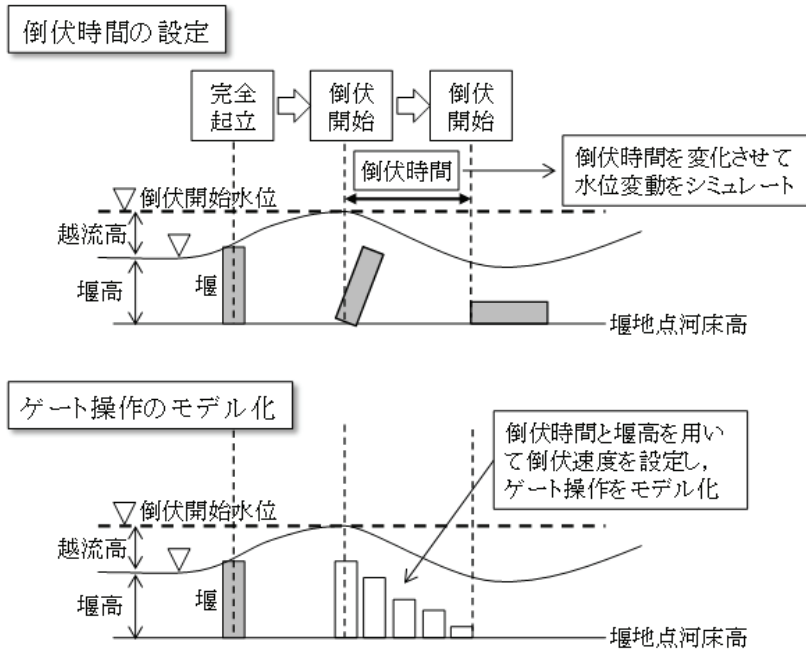

図 6: 可動堰倒伏のモデル化の概要

\section{3 境界条件とモデルの構造}

本研究で構築した一次元不定流解析モデルの模式図を 図 7に示す。対象区間の下流端の境界条件には，川島 観測所の時間当たりの流量データを用いた（国土交通 省，2015）. 合流河川からの流入量については実測值 がないため, 図 7の(1)〜 (3)の流入量は大隈観測所の流 量から合流部の流域面積(CA)比を用いて推定した比流 量を入力した。また，(4)およ゙5)の流入量は(4)の上流 に位置する秋松観測所（図 1）の流入量を用い，同様 に比流量を求めて設定した。

\section{4 結果と考察}

\section{1 統合堰の倒伏時間の検討}

ダムの管理例規集 (国土交通省, 2006)によると, ダムから の放流による下流水位の上昇は, 基準地点において 30 分 間で30〜 50cmに収まることを推奨している.これを踏まえ， 本研究では, 統合堰のゲート操作によって生じる下流への 水位変動が 30 分間に $50 \mathrm{~cm}$ 以内に収まるような倒伏時間を 探索する.

計算に用いた条件を表 3に示す. 本研究では, 1991年 から2009年に生じた6洪水のうち, 大隈観測所でのピーク 流量が最も高かった2006年7月4日をモデルケースとして 解析を行った. 国土交通省(2015)によって測定された7月 3 〜6日の川島および大隈観測所における水位および流量 の経時変化を図 8に示す.7月4日は $102 \mathrm{~mm}$ の日雨量が 記録されており，これによって河川水位が急激に上昇して 洪水が発生した。この図より, 大隈観測所では降雨によっ て夜間に水位が上がり始め, 22 時に水位および流量のピ 一クが生じている. また, 川島観測所でも, 河川流量およ び水位の上昇は22時にピークに達しており, 大隈に比べ ると流量のピークは極めて大きな值を示している.これは, 図 7のモデルに示した他の流域や河川からの流入に起因 していると考えられる.

図 8に示した3日間の境界条件を用いて不定流解析を 行い, 対象区間の水位変動を推定した.まず, 統合堰の 倒伏時間を20分, 30分および40分の3段階に設定して下 流の水位変動を明らかにし, 統合堰の最適な倒伏時間を 求めた. 図 9は, 統合堰の倒伏時間を3段階に変化させて 


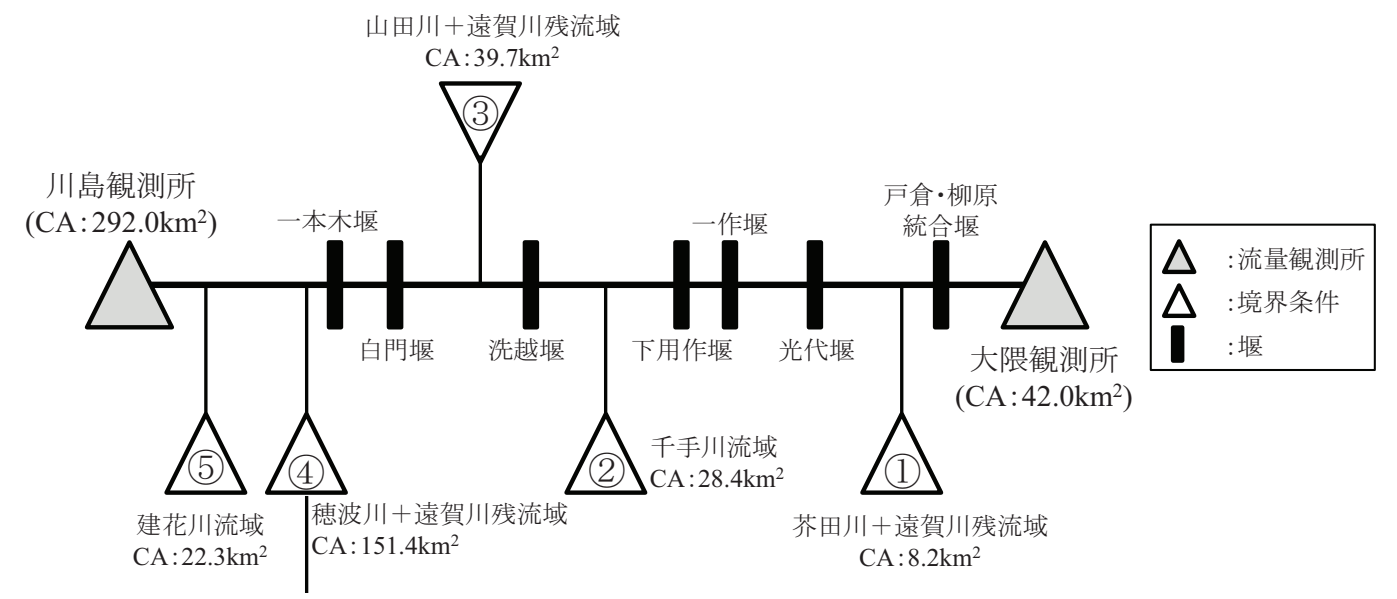

図 7: 一次元不定流解析モデルの構成

表 3: 計算条件

\begin{tabular}{|c|c|}
\hline 項目 & 条件 \\
\hline 計算期間 & 2006 年 7 月 4 日 -7 月 6 日 \\
\hline 対象区間 & 川島 $(30.0 \mathrm{k})-$ 直轄上流端 (47.6k) \\
\hline 境界条件 & $\begin{array}{l}\text { 上流端流量 : 大隈観測所の実測値 } \\
\text { 下流端流量 : 川冒観測所の実測值 } \\
\text { 支線流入量 : } \\
\text { 近傍の流量実測值を用いた比流量 }\end{array}$ \\
\hline $\begin{array}{c}\text { 時間ステップ } \\
(\mathrm{s})\end{array}$ & $0.1-0.5$ \\
\hline $\begin{array}{c}\text { 河道断面格子 } \\
\text { 間隔 }(\mathrm{m})\end{array}$ & 200 \\
\hline 粗度係数 & $\begin{array}{c}\text { 計画時の粗度係数を適用 } \\
40.4 \mathrm{k}-42.6 \mathrm{k}: 0.033 \\
42.8 \mathrm{k}-47.6 \mathrm{k}: 0.038\end{array}$ \\
\hline $\begin{array}{c}\text { 倒伏開始水位 } \\
(\mathrm{m})\end{array}$ & 0.27 （越流水深） \\
\hline $\begin{array}{c}\text { 倒伏時間 } \\
\text { (min) }\end{array}$ & 20 分, 30 分, 40 分 \\
\hline
\end{tabular}

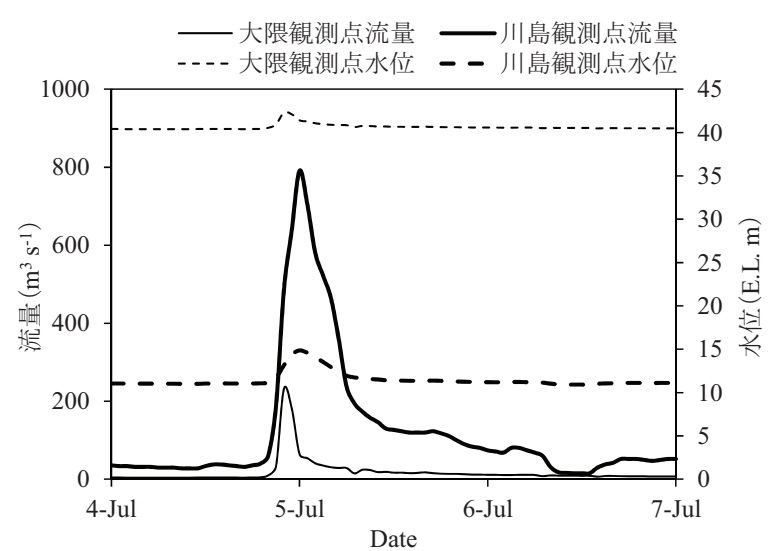

図 $8:$ :島および大隈観測所地点における流況の経時 変化

推定した下流の水位変動を示している.この計算では, 統 合堰の操作の影響を抽出するため, 他の堰は倒伏させて いない.この図より, 統合堰の倒伏によって, 約 $800 \mathrm{~m}$ 下流

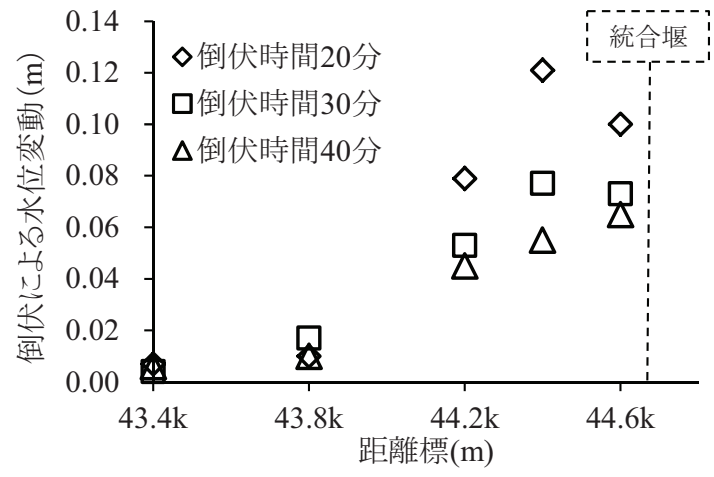

図 9: 統合堰の倒伏時間と下流部の水位変動の関係

の水位まで影響が及んでいることが明らかである. また, 倒 伏時間が短いほど，下流の水位変動が顕著であることが 示された. 水位の変動は, 堰の直下よりも約 $200 \mathrm{~m}$ 離れた 地点のほうが大きく, 倒伏時間20分のケースで特に水位 上昇が大きいことが明らかである. 遠賀川水系における取 水堰の管理規程では, 堰ゲートの倒伏による下流部への 水位変動は 30 分間で $0.3 \sim 0.5 \mathrm{~m}$ の範囲に収めることが求 められている. 本研究で設定した3段階の倒伏時間のいず れも, 下流部の水位変動はこの範囲内に収まっていた. 実 際の現場での管理者の安全面を考慮すると, 水位変動が 最小となる40分とすることが適切であるといえる.

\section{2 統合堰の倒伏時間の検討}

6つの可動堰の倒伏速度が河道全体の水位変動に及ぼ 寸影響を評価するため, 全ての可動堰地点の倒伏時間 を3段階に設定し, 水位が倒伏開始水位に達した時に堰 のゲートを倒伏させ，これに伴う河道全体の水面追跡 を行った. 堰の倒伏時間は, 統合堰で求めた 40 分を標 準時間とし,20分, 40分および80分の3段階に設定した. 可動堰6か所を3段階の倒伏時間で操作するため, 倒伏 パターンの組み合わせは729ケースとなり,これら全て のケースで対象区間の水位変動を推定した。ここでは 表 4に示したケース1から4の条件下の計算結果を図 10に示寸，なお，全てのケースにおいて水位の変動を 比較したところ, 堰群の操作によって水面形の違いが 出ていたのは $35.2 \mathrm{k}$ 付近までであるケースが大半であ ったため, それよりも上流の範囲を図示している. 図 8 に示した通り, 大隈観測所では7月3日の22時に最大流 
表 $4:$ 水面追跡の条件

\begin{tabular}{c|l}
\hline ケース No. & 堰の倒伏時間 \\
\hline ケース 1 & 全ての堰 : 40 分 \\
\hline ケース 2 & 統合堰 : 20 分 \\
& 他の堰 : 40 分 \\
\hline ケース 3 & 統合堰 : 80 分 \\
\hline 他の堰 : 40 分 \\
\hline ケース 4 & 全ての堰 : 20 分 \\
\hline
\end{tabular}

量を記録しているが，統合堰付近の水位が越流水深に 到達したのはいずれのケースでも約2時間後（7月3日0 時前後）であった。図 10(a)より，ケース 1 ，ケース 2 およびケース4ではこの時間における水面形の違いは ほとんど現れていない。これらのケースでは, 固定堰 である洗越堰が存在する $39.8 \mathrm{k}$ 付近の水位は全てのケ 一スで非常に高くなり, 堤防高付近まで上昇している. したがって, これらの3ケースの操作では洪水の危険性 が高く, 倒伏開始の水深や倒伏時間を見直す必要があ ることを示唆している。一方，ケース3では，下流部の 水位は他のケースよりも低い結果となった。これは, 統合堰を標準よりもゆっくりと転倒させたため, 下流 部に急激な洪水流下が生じず，水位変動を抑制したと 考えられる. しかし，ケース3においても，固定堰付近 の水位は堤防高付近まで上昇していることから, 固定 堰が存在する河道区間では特に慎重なゲート操作が不 可欠であり，これを考慮して可動堰への改修なども検 討することが必要であるといえる. 図 10(b)に示した7 月4日2時の水面形において, ケース3をその他と比較す ると統合堰下流部の水位が低い傾向維持されているこ

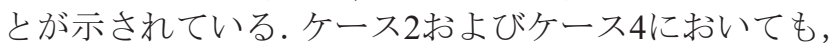
統合堰直下流部の水位はケース 1 に比較すると低い状 態になっている。図 10(c)は7月4日4時における水位の 空間分布を示している。この図より, 堰ゲートの倒伏 から4時間経過後すると, 倒伏パターンによる水面形の 違いは約 $2 \mathrm{~km}$ から $7 \mathrm{~km}$ の下流部付近で顕著に表れてい る. 図 10(b)に比較すると, ケース 1 , ケース 2 小よび ケース3はいずれも水位が時間とともに低下している ことが明らかである.水位の低下はケース 3 で最も顕著 である。一方，ケース4においては2時間前の結果と比 較すると水位が約 $0.5 \mathrm{~m}$ 上昇している. 同時間の他のケ 一スと比べた場合でも水位は高い值となっており, 固 定堰付近では堤防高との差が $1 \mathrm{~m}$ 程度になるまで上昇 している。倒伏パターンに伴う水位の変動の空間的な 違いは, 図 10(d)に示した通り, 堰倒伏から6時間後に は解消されていた。

\section{5 おわりに}

本研究では, 複数の取水堰が設置されている河川にお いて, 複数の堰のゲート操作による河川の水位変動を 明らかにして適切な管理規程を求めることを目的にし， 遠賀川上流部を対象にして一次元不定流モデルを構築 した. 洪水時の流量を境界条件とし, 新設された可動 堰の最適な倒伏時間を探索した。その結果, 統合堰の 単独の操作によって, 約 $800 \mathrm{~m}$ 下流部まで水位変動が

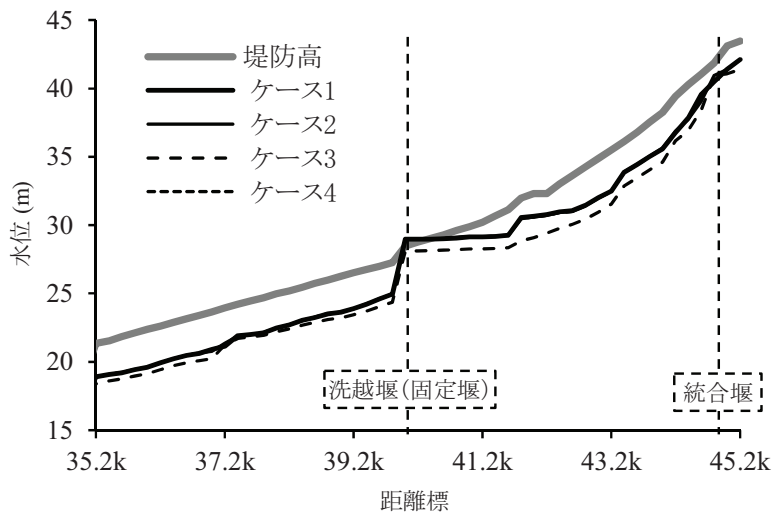

(a) 2014 年 7 月 3 日 0 時

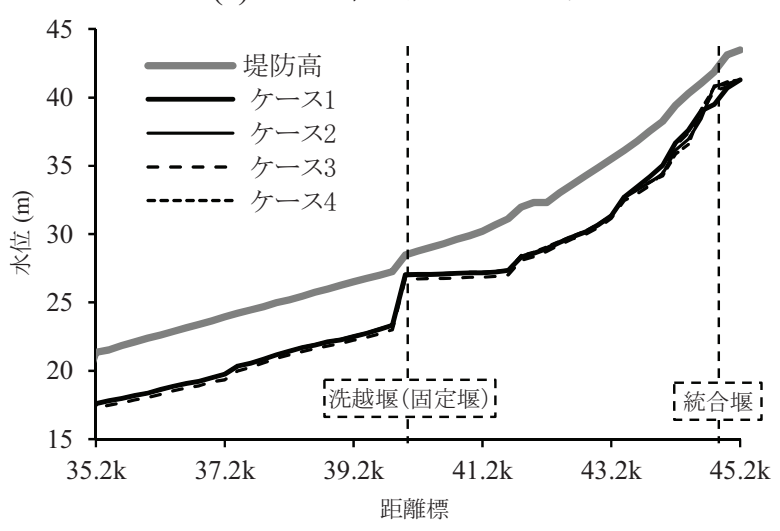

(b) 2014 年 7 月 4 日 2 時

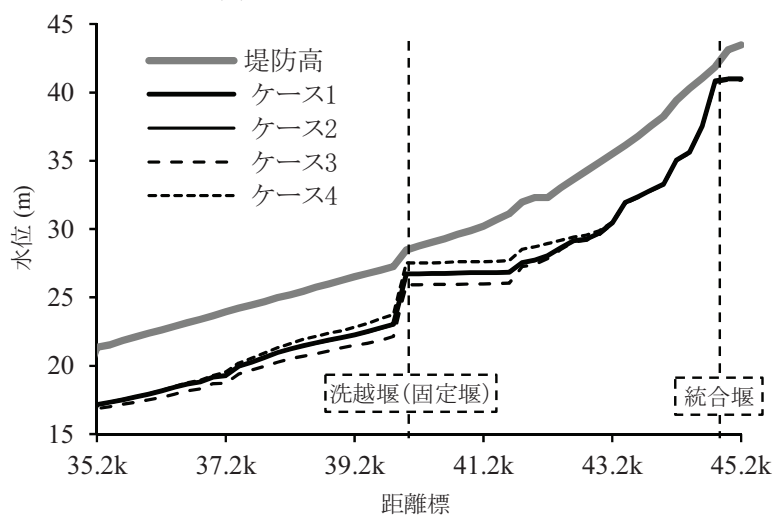

(c) 2014 年 7 月 4 日 4 時

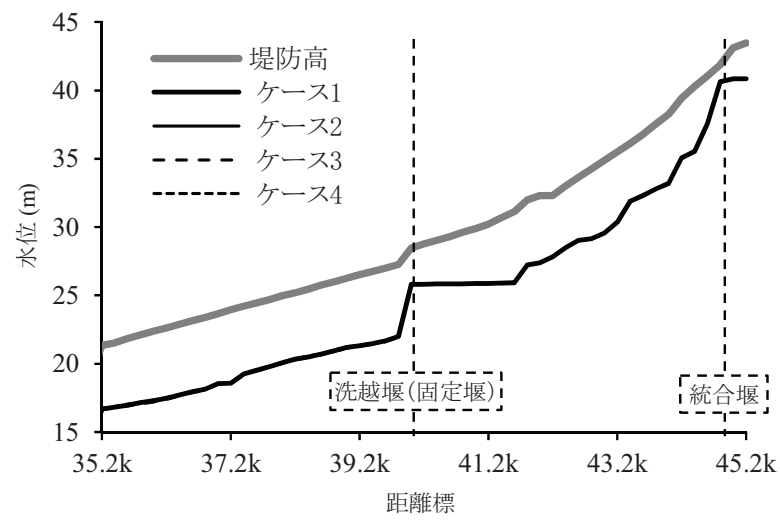

(d) 2014 年 7 月 4 日 6 時

図 $10:$ 堰倒伏による河川水面形の変化 
生じることが明らかになった，下流部に生じる水位変 動を極力抑制するには, 統合堰の倒伏時間は 40 分と規 定することが最適であると判断することができた.

この結果を用い, 対象区間内の堰群の操作が対象区 間全体の水位変動に及ぼす影響を明らかにするための 解析を行った. 全ての可動堰地点の倒伏時間を 3 段階 に設定し，水位が倒伏開始水位に達した時にそれぞれ の倒伏時間をかけて堰ゲートを倒伏させ，これに伴う 河道全体の水面追跡を全ての倒伏パターンで行った. その結果，堰群のゲート倒伏時間を短く設定すると， 下流部の水位が上昇する傾向となった。特に, 下流部 に固定堰が存在する場合には, その付近での堰上げに よる水位上昇が顕著であり，洪水の危険性が高まるこ とが示唆された. 一方, 上流部の堰の倒伏を比較的長 い時間をかけて行うと，下流部の水位上昇を抑制する ことができ，著しい影響を避けることが可能であるこ とが示された。一般に洪水の際には速やかなゲート操 作を行って洪水を迅速に流下寸ることが求められるが, 急激な流下が下流部に伝播して水位の著しい上昇や下 流部での溢水を誘発する恐れがある場合もあることが 明らかになった。 以上より, 堰群のゲート操作は複雑 に下流部に影響を及ぼすため，相互の影響を踏まえて 慎重に倒伏条件を定めてゲート操作を行う必要がある といえる。

本研究で構築した手法により, 取水堰群の個々のゲ 一下操作を考慮した河川の水位変動を予測することが 可能である. 堰ゲートの倒伏による影響範囲を明らか にすることができ，下流に著しい変動を及ぼさず，な るべく速やかに洪水に対応できるような最適な堰の操 作手法を具体的に提案することができる. 本研究によ り, 洪水時における取水堰のゲート操作の安全性およ び迅速性を向上させる手法の確立に資する成果が得ら れたといえる. 今後は, 洪水時に発生する土砂輸送を 考慮に入れるなどしてモデルをより現実に近いものに 改良することを目標としたい，また，本研究では，非 常に多数のケースでの計算を行ったため, 計算時間が 長大となった。 今後は本研究で得られた解析結果を活 用し, 最適化手法を導入するなどしてゲート操作の最 適解を探索する手法の確立を目指寸予定である.

\section{謝辞}

本論文は福岡県土地改良事業団体連合会より委託を受 けた「戸倉堰・柳原堰災害実施設計書作成業務」(平成
23年度）の成果をもとにまとめたものである. 関係各 位に記して謝意を表します。

\section{引用文献}

[1] Abbott M. B., and Ionescu F. (1967): On the numerical computation of nearly horizontal flows, Journal of Hydraulic Research, 5(2), pp. 97-117.

[2] DHI (2009): MIKE 11 A Modelling System for Rivers and Chanels. Reference Manual, Danish Hydraulic Institute, Denmark, pp.524.

[3] Kamel A. H. (2008): Application of a hydrodynamic MIKE 11 model for the Euphrates river in Iraq, Slovak Journal of Civil Engineering, 2, pp.1-7.

[4] 勝山達郎・内村求・樽屋啓之 (2012): 農業水利施設の管 理における多様な主体の参加と特定受益者賦課に関す る考察, 農業農村工学会論文集, 280, pp.45-51.

[5] 国土交通省 (2015): テレメータ 雨量・水位・水質・積雪, 川の防災情報, www.river.go.jp/. (参照:2015/1/26)

[6] 国土交通省 (2006): ダムの管理例規集, 山海堂, pp.731.

[7] 中達雄・常住直人・桐博英・小林宏康・加藤敬 (2002):頭 首工の取水管理の高度化および取入口計画・設計のマ ニュアル化に関する研究, 農業工学研究所技報, 200, pp.75-96.

[8］中橋秀順・以倉直隆・元平幸成・桐井健一 (2006): 操作 時のヒューマンエラー対策とメンテナンスフリー 〜大坪用 水堰ゲート設備における維持管理上の工夫〜, 北陸地方 整備局管内技術研究会論文集, 2006, pp.433-436.

[9] 鈴木洋之・谷口友梨・河村陽一 (2011):庄川の連続ダム 群における推定流量の精度劣化要因, 水文・水資源学会 誌, 24 (3), pp.149-158.

[10] 竹村吉晴・福岡捷二・浅見和人 (2010): 小規模発電ダ ムが連続する河道における洪水流の伝播と貯留効果につ いて, 水文・水資源学会誌, 23(2), pp.129-143.

[11] Timbadiya P. V., Patel P. L., and Porey P. D. (2014): One- dimensional hydrodynamic modelling of flooding and stage hydrographs in the lower Tapi River in India, Current science, 106(5), pp.708-716.

[12] Wijesekara G. N., Farjad B., Gupta A., Qiao Y., Delaney P., and Marceau D. J. (2014): A comprehensive land-use/ hydrological modeling system for scenario simulations in the Elbow River watershed, Alberta, Canada. Environmental Management, 53(2), pp.357-381.

この論文の公開の質疑または討議は2016年6月30日 まで受付けます。 